\title{
Audit pricing in Nigerian banking industry: A panel analysis (2008-2012)
}

\author{
AJIDE, Folorunsho Monsuru \\ School of Management and Business Studies(SM\&BS) Lagos state polytechnic, Ikorodu
}

\begin{abstract}
This paper examined the determinants of audit pricing in Nigerian commercial banking industry. Panel data analysis had been carried out to find out the determinants of audit fees with variables such as banks' complexity, risk and operating performances as the explanatory variables and audit fees as the explained variable. Fourteen (14) commercial banks were selected out of twenty-two which made up the population. Data were sourced from the annual reports and accounts of the selected banks for the year 2008 to year 2012 period. The Fixed effect firm model estimations revealed that there is a positive association of complexity, risk, but negative association between operating performances and audit fees.It was concluded that there is high influenced and significant relationship between the audit fees and the explanatory variables in the study.
\end{abstract}

Keywords: audit market, panel analysis, audit fees, bank complexity.

\section{Introduction}

The Companies and Allied Matters Act (enhance forth, CAMA) CAP C20, LFN 2004 is the principal law which sets the tone for the incorporation and conduct of business in Nigeria. In Nigeria, financial statements are prepared with the objective that they present a true and fair view of the state of affairs of the entity and of the profit or loss for that period, and comply with the Companies and Allied Matters Act, CAP C20, LFN 2004. The Banks and Other Financial Institutions Act 1991(enhance forth, BOFIA) regulates the operations of banks and other financial institutions in Nigeria. It makes it mandatory for every commercial bank in Nigeriato audit their accounts which have a profound effect on the reliability and availability of financial information. Section 357 of the Companies and Allied Matters Act provides for the appointment of auditors which states thatevery company shall at each annual general meeting appoint an auditor or auditors to audit the financial statements of the company, and to hold office from the conclusion of that, until the conclusion of the next, annual general meeting. It follows that every corporation registered with the corporate Affairs Commission; however, a public corporate body in Nigeria needs to undergo an annual audit of its financial statements by an independent registered public accounting firm (see CAMA, 2004).

The BOFIA as amended to date also further states that every bank shall appoint annually a person approved by the CentralBank of Nigeria, referred to as "approved auditor", whose duties shall be to maketo the shareholders a report upon the annual statement of financial positions and comprehensive income statements of the bank and every such report shall containstatements as to the matters and such other information as may beprescribed, from time to time, by the Central Bank. And, that any bank fails to appoint an approved auditor, the Central Bank shall appoint a suitable person for that purpose and shall fix the remuneration to be paid by the bank to such auditor (see BOFIA, 1991). These audited financial statements are important because they serve as the source of financial measures used by stockbrokers, financial analysts and other stakeholders to evaluate financial performance. Swanson (2008) stated that audited financialstatements give analysts and investors greater faith in the validity of thefinancial statements. The importance of the statements suggests thatmeasures of size and financial performance will affect the audit feescharged to clients of the audit firms (Swanson, 2008; Simunic, 1980).

To supplement the above points, some views state that audit fees charged by audit firms can also increase with an increase in the risk to which a client is exposedto,its complexity and financial performances(see the work of Stice, 1991; Hackenbrack\&Knechel, 1997; Hay, Knechel\& Wong, 2006). However, audit company attributes are also considered important drivers of audit fees. Size, reputation, experience, competition, industry specialization and whether it is from the Big Four are aspects of the audit company attributes that influence audit fees( see Francis, 1984; Palmrose, 1986; Larcker\& Richardson, 2004, Gonthier\&Schatt, 2007; Francis \& Simon, 1987; Butterworth \& Houghton, 1995).

Interestingly, this paper intends to examine the determinants of audit fees in Nigerian bank industry. Thestudy of Akinpelu, Omojola, Ogunseye\&Bada (2013) who investigated the determinants of audit fees in commercial banks in Nigeria employed a cross-sectional data analysis with the use of thirteen commercial banks which were in operation in year 2009. This simplifies that the study of Akinpeluet. al (2013) only cover year 2009 only. However, the uniqueness of this present study is that firstly, it uses panel data analysis covering year 2008 to 2012 which makes a five- year point and secondly, fixed effect model estimation has been adopted 
which takes of care the heterogeneity of different banking firms in the industry. The remainder of this paper is sectioned into four. The next section deals with literature review followed by methodology, discussion of results and conclusion ends discussion.

\subsection{Theoriesof Audit Services}

\section{Literature Review}

There four major theories normally used to theories of audit services as given byHayes ,Schilder, Dassen \& Wallage (2005):

1. The policeman theory: In the early 20th century, it wasclaimed that the auditor was responsible for searching,discovering and preventing fraud. However, more recently the main focus of auditors has been to providereasonable assurance and verify the truth and fairness of the financial statements.

2. The lending credibility theory: itsuggests that the primary function of the audit is toadd credibility to the financial statements. In this view, Ittonen( 2010) states that the service that theauditors are selling to the clients is credibility. Audited financial statements areseen to have elements that increase the financial statement users' confidence inthe figures presented by the management (in the financial statement). The users'are perceived to gain benefits from the increased credibility, these benefits are typically considered to be that the quality of investment decisions improve whenthey are based on reliable information.

3. The theory of inspired confidence:Limperg (1932) discussed the demand and the supply for audit services. The demandfor audit services is the direct consequence of the participation of third parties in the company. These parties demandaccountability from the management, in return for their investments in thecompany.Ittonen( 2010) stated that accountability is realized through the issuance of periodic financial reports.However, since this information provided by the management may be biased, andoutside parties have no direct means of monitoring, an audit is required to assurethe reliability of this information.

4. Agency theory: A company is viewed as a web of contracts. Stakeholders make some kind of contribution tothe company for a given price and they expect reasonable returns .In these realationships, management is the agent, whichtries to gain contributions from principals. It is important that management protects the interest of different stakeholders in the business decision making. Ittonen( 2010) hinted that the most prominent and widely used audit theory is the agency theory because the roles of auditors come to play due to problems that arise from theprincipal-agent relationship. the diagram below shows the various theories of audit as summared by Ittonen ( 2010)

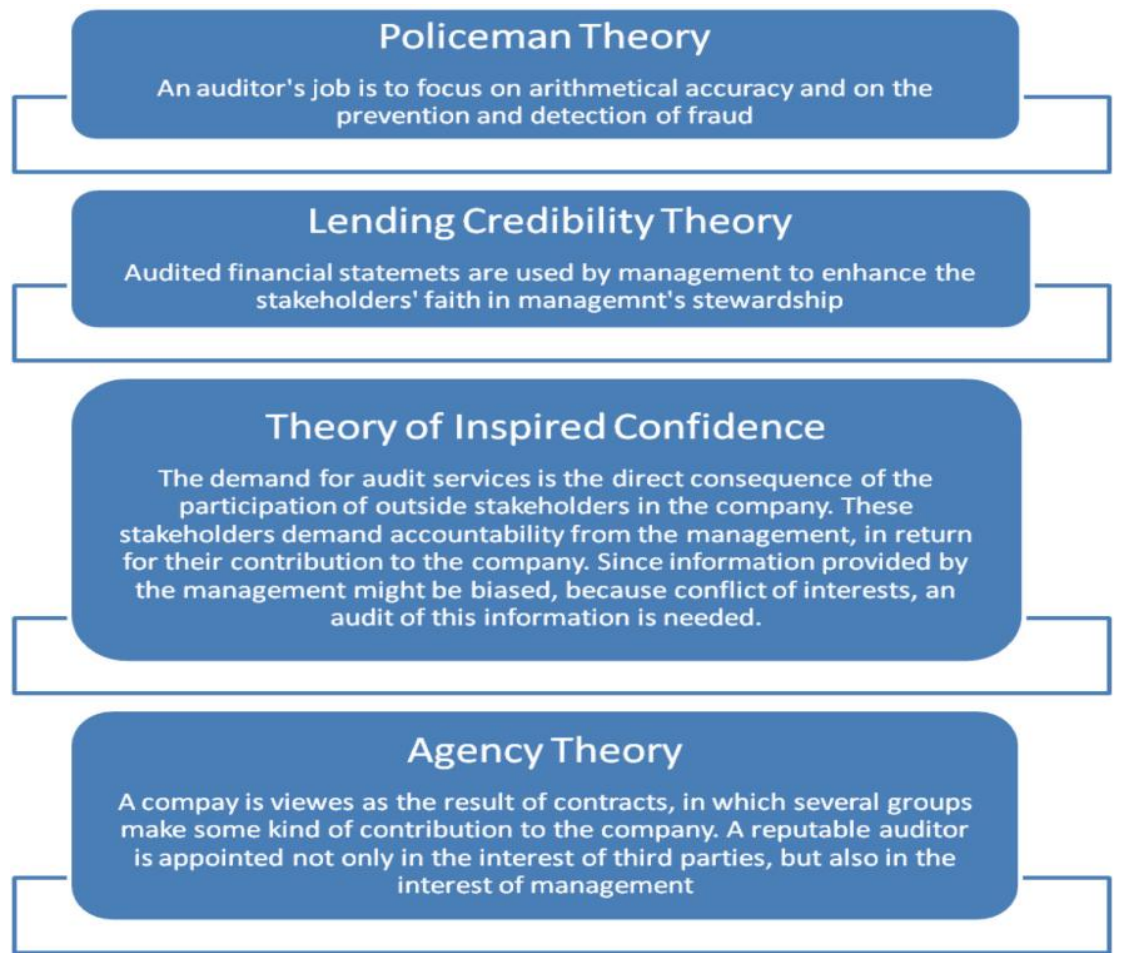

Source: Adapted from Hayes ,Schilder, Dassen \& Wallage (2005) as cited inIttonen( 2010).A Theoretical examination of the role of auditing and the relevance of audit reports.Proc. of the University of Vaasa. Teaching Aid Series, VaasanYliopistonJulkaisuja,P. 4. 


\subsection{Economic features of an audit market}

As well known, the market for audit services exhibits a set of features that distinguish it from other markets for business services ( Gerakos\&Syverson, 2013). The following are the silent features:

1. Capital market transparency: Firstly, it is observed by manyauthors (for instance, Watts \& Zimmerman (1983), Black (2001), and Ball (2001)) to play an important and in some ways a unique role in preserving transparency and improving the functioning of capital markets. Hence, inability by financial auditors to catch and report improprieties is often highly and occasionally spectacularly visible.

2. Mandatory demand: a significant portion of demand in the market is mandated. Public companies arecompelled by laws to purchase audit services, and there are no services from outside the industry that canlegally serve as substitutes. That is, no substitute for the audit services.

3. Concentrated supply: the market's supply side is highly concentrated. Among public companies in Nigeria especially Bank industry., for example, the majority of audit engagements and almost all audit fees involve just four audit firms ( that is Big 4: Ernst \& Young, Deloitte-Akintolawilliams, KPMG, and PricewaterhouseCoopers).

4. Indivisible products-Doogar\& Easley(1998) explained audit market features by saying that in such market clients buy the entire audit from one firm. This all-or-nothing nature of audit demand makes audits indivisible. Second, because of this indivisibility, the distribution of client sizes affects the pattern of audit firms' market shares. Third, differencesin labor productivity across firms affect audit costs. Jointly, thesethree features can enable us to predict audit market concentration.

5. Cost efficiency criteria- it seemed to predict that audit services market is becoming increasingly competitive. To offer audit services at competitive prices, information on the costs of conducting audit engagements is essential (Schelleman\& Maijoor,2001). Specifically, given a specific level of audit quality, audit firms of whatever size need to know the minimum amount of costs necessary to effectuate particular audit engagements. That is, information on the cost efficiency of audit engagements is necessary. Schelleman\&Maijoor(2001) further explained that audit firmsare professional service organizations whose most important input is human capital, themajority of the costs associated with audit engagements consist of costs for use of laborhours. This implies that audit firms also need information on (the minimum amount of) laborhours to compete effectively with other audit firms on the dimension of audit pricing.

\subsection{Demand for Audit in banking industry}

On demand for audit services, the American Accounting Association's (AAA) Committee on Basic Auditing Concepts (1973) as cited by Ittonen( 2010) summarized the criteria that create the demand for auditing as thus: the potential or actual conflict of interest, Consequences of errors, Complexity, Remoteness.

Firstly, the demand for auditing services may arise from the existenceof conflict of interest between the preparer(the bank management) of the information and the user(shareholders, creditors, government, bank customers, etc). This circumstance may cause the information to be biased, i.e. the manager is allowedto choose the method, extent and timing of the reporting. This may make the qualityof information suspect and necessitate an independent review of the information, an audit.

Ittonen( 2010) stated that two sources of conflict of interests may be identified related to corporate reporting,deliberate and unintentional. First,management may deliberately prepare anddisclose biased information to pursue personal interests(selfish interest). Second, unintentional biasin financial information could exist if bank management, without realizing, attempts tosatisfy the needs of one outside interest group at the expense of the others. Thebank manager may please the interests of their creditors to gain favorable loanterms or to meet the debt covenants. In another direction, management may strive tosatisfy the needs of significant owners, at the expense of other owners. One of majorobjectives of auditing is to ensure unbiased reporting which could benefit one interestgroup( especially the managers) at the expense of the others.

Secondly, as illustrated by Ittonen( 2010), the demand for auditing may also be attributed to the significant economic,social or other consequences of users' erroneous decisions. To increasethe quality of their decision making, investors need reliable and complete information. The audit function adds to the credibility of the underlying informationand, as a consequence, users may rely more on the information and make moreaccurate evaluations.

Thirdly, both accounting and preparation of financial statements are becoming moreand more complex. Similarly, the interpretation of financial statements also requiresthorough understanding of accounting and reporting practices, businessprocesses governance issues, institutional settings and other banks' laws and regulations. Users are therefore findingit more and more difficult (or even impossible) to evaluate the quality of financialstatements and interpret the signals of the disclosures. Complexity of the reportingprocess may also increase the risk of unintentional errors due to the lackknowledge of the preparer. Furthermore, the average user 
of financial information may lack the average knowledge of knowing good quality financial reports. Hence, the auditor is hired to provide users an assessment of the quality of theinformation.

Fourth, typically the users of banks 'financial statements do not have, due to legal andinstitutional barriers, direct access to the accounting records from which financialstatements are prepared. Furthermore, if the accounting records would be madeavailable for assessment, time and cost constraints normally prevent users frommaking a meaningful investigation due to different branches being held by banks. Remoteness prevents users from directly "auditing"the financial statements themselves. Due to these restrictions users mustrely on a third party, the audit firm, to assist them in assessing the quality of financialinformation, or accept the quality of the financial data in good faith.

In conclusion,Ittonen(2010) stated that the last four conditions are based on the theory of rational expectations. The concept of rational expectations assumes that people take intoaccount all available information that influences the outcome of their decisions. Further, it expects people to utilize their information intelligently and thereforethey do not systematically make mistakes (i.e. they learn from the past).

\subsection{Review of previous contributions}

Based on the previous studies, the determinants of audit fees can be classified into two major headings : client attributes and auditor attributes. The client attributes have received much attention in previous studies. Those studies included the characteristics of size, complexity, risk, and profitability of the firm being audited in the models (El-Gammal,2012). Consistent with the theory on audit effort and litigation, audit fees tend to increase with an increase in the client's size (e.g. Simunic, 1980), risk (e.g. Stice, 1991), complexity (e.g., Hackenbrack\&Knechel, 1997), and profitability (e.g., Hay, Knechel\& Wong, 2006).However, audit company attributes are also considered important drivers of audit fees. Size,reputation, experience, competition, industry specialization and whether it is from the Big Four are aspects of theaudit company attributes that influence audit fees. Also, many prior studies suggested that audit fees increase with the Auditfirm's Size (Francis, 1984; Palmrose, 1986), reputation (Larcker\& Richardson, 2004, Gonthier\&Schatt, 2007), experience, industry specialization (Pearson \&Trompeter, 1994; Cullinan, 1998) andwhether it is one of the Big Four (Palmrose, 1986; Francis \& Simon, 1987; Butterworth \& Houghton, 1995). In addition, audit fees decreases with the increase in competition, the greater the number of competitors the lowerthe audit fees are charged (e.g., Maher, Tiessen, Colson\& Broman, 1992). Currently, there are various published works on the relationship between audit fees and its determinants. Among them are discussed below:

Friis\& Nielsen(2010) analyzed whether the application of IFRS standards has increased Danish companies' cost of auditing. The study is based on a sample of financial reports from large Danish companies from 2002 to 2008. Controlling for a number of general audit fee driving aspects, they find that overall, audit fees have not increased significantly for companies using IFRS rules. However, when combining IFRS with company size and complexity, they find that large and complex companies using IFRS pay a heavy audit fee premium compared to small and less complex companies that also use IFRS. The results for non-audit fees are less conclusive.

Ali \&Amiens (2011) examined whether auditors are employed as a monitoring mechanism to mitigate agency problems between controlling shareholders and minority shareholders (named Type II agency conflict). In a context of ownership concentration and poor investor protection, controlling shareholders can easily expropriate minority shareholders and profit from private benefits of control. However, they state that this agency conflict has been rarely studied, as the most commonly assumed agency conflict resides between managers and shareholders (Type I). Using an audit fees model derived from Simunic (1980), they studied the impact of type I and type II agency conflicts on audit fees in high vs. low investor protection countries. They then focused on two countries (Germany and France) providing a lower investor protection level, and two countries (the USA and UK) providing a higher investor protection level. The results show 1) a negative relation between audit fees and managerial shareholding, which is stronger for strong than for low investor protection countries; 2) a curvilinear (concave) relation between audit fees and controlling shareholding for low investor protection countries; 3) a lower Type II conflict in the strong investor protection countries. These results illustrate the mixed effects of the legal environment and both agency conflicts on audit fees.

El-Gammal(2012) studied the views of external auditors and client's representatives (accountants, financial controllers and internal auditors) about the factors that affect determining audit fees and provides evidence whether thesefactors are related to audit firm characteristics or the client firm characteristics. A sample of 80 respondentsprovided the empirical data for the research by answering a self administered questionnaire. To conduct dataanalysis descriptive statistics, means, standard deviation and Mann-Whitney U test were used. The outcome ofthe study provides a vital insight into the determinants of audit fees from a developing country like Lebanon. Itwas found that all the pre-suggested determinants of audit fees are extremely important or important. Bothexternal auditors and client representatives groups agree that the most important factor affecting determiningamount of audit fees is whether the audit firm is one of the big four or notand the least important 
factor is thesize of the audit firm based on the number of its employees. The results also show that the degree of importanceof each determinant of audit fees is homogenous among the two groups of respondents.

Ellis \& Booker (2011) investigated the determinants of audit fees in the Community Action Agency (anti-povertyfighting nonfederal organizations) segment of the NPO sector of the audit market. An externalaudit fee model is developed using a national sample of 274 Community Action Agencies.Ordinary least square regression is used to test the model. The findings indicate that the model ishighly significant and explains the majority of the cross-sectional variance in audit fees.Consistent with prior studies, the size and complexity variables explain the majority of variancein fees. Contrary to prior studies, there is a weak association between the proxies for risk andfees and there is a low concentration of Big audit firms. This segment of the audit market isdominated by small (non-Top 100) audit firms.

Hassan\&Naser (2013) examined factors influencing audit fees paid by non-financial companies listed on AbuDhabi Stock Exchange (ADX). Data were collected from the 2011 annual and corporate governance reportspublished by the Emirati non-financial companies listed on ADX. Backward regression analysis is employed toassess the association between audit fees and certain company's attributes. The findings show a directrelationship between audit fees and each of corporate size, business complexity and audit report lag variables. An inverse relationship has been detected between audit fees and each of industry type and audit committeeindependence. The findings also revealed that audit fees are not significantly influenced by company'sprofitability, risk, and status of audit firm.

Ionela-Corina, Ioan-Bogdan, Mihai\&Marilena(2012) aimed to identify the determinants ofthe audit fees, by testing the existence of a circular causality in the connection between auditfees and the financial performance of a NYSE-quoted company. The analysis is based on asample of the first 100 companies (NYSE quoted) of the Top 500 Fortune, except for thecompanies in the investment funds and insurances field. In the study there were tested andvalidated the following working hypothesis: "the level of the audit fees is mainly influenced bythe company's capacity to continue its activity", "the prestige of the audited companycontributes to the decrease of the audit fees" and "the reduced fees level, paid by the customeraudited by one of the Big4 companies in this exercise, contributes to the future prestigeincrease". For data analysis they used linear regression analysis (simple and multiple)and the variance analysis (ANOVA). Research results indicate the existence of a circularcausality, bidirectional, on the level of the relationship between audit fees and financial performance.

Shammari,Yaqout\&Hussaini (2008) investigated the audit market in Kuwait. They developed a model for the determinants of audit fees that took into account client size, risk, complexity, profitability, industry and auditor. The findings show that there are similarities in the determining factors for audit fees in Kuwait and other countries previously studied. However, it was also found differences. Contrary to the findings of most of the other studies there is no fee premium in Kuwait for the Big Four auditing firms. This study shows that the level of audit fees is positively associated with client size and complexity of client operations. Other variables are not significant.

Hallak\& Silva (2012) aimed to identify the factors affecting the auditing and consulting expenditures in Brazilian public companies. The study was motivated by the lack of studies on auditing and consulting expenses in Brazil, whereas this matter has been researched for years in other countries. Data on Brazil are scarce because the disclosure of spending on auditing and consulting services provided by independent auditors only became mandatory in 2009. The disclosure of these data enables the analysis of the drivers of the fees paid by companies for these services. In the study, it was only analyzed the expenditures for consultancy services provided by the same auditing firm; that is, they ignored all spending on other consultants. The results indicated that audit fees are positively related to company size, corporate governance quality, and the Big Four status of the auditor. In terms of consulting expenses, there is a positive relationship between company size and Big Four status, but there is no significant relationship with corporate governance. In addition, Swanson (2008) examined the effect of size and financial position on audit fees using regression analysis. The model shows a direct relationship between measures of both assets and revenues and the audit fees that firms are charged. $\mathrm{He}$ concluded that measures of size do have an effect on the price of audit services in the U.S. financial services industry.

Furthermore, Akinpelu, Omojola, Ogunseye\&Bada (2013) also investigated the determinants of audit fees in commercial banks in Nigeria. Data were collected from a sample of banks mostly quoted on Nigerian Stock Exchange. Consistent with previous studies, the results showed that bank size, degree of bank complexity and transaction and saving accounts to total deposit ratio are positively related and statistically significant to audit fees charged by the auditors. Even though, non performing loan is positively related to audit fees, it is statistically insignificant. While, the risk weighted capital adequacy ratio is negatively related and statistically insignificant to audit fees. 
In conclusion, most of the previous studies have analyzed the determinants of audit fees in a cross sectional manner without analyzing, using a combination of cross-sectional data and time series data called panel data. However, this present study intends to fill this gab by studying the relationship between audit fees and its determinants in Nigeria using panel data approach.

\section{Methodology}

To construct the sample, 14 commercial banks in Nigerian economy were selected which represented about $64 \%$ of the population (since 22 banks are operating as of year 2013). The study covers a period of five years from 2008 to 2012. It can therefore be summarized that the study employed 70 observations. The study is based primarily on the secondary data collected from the annual reports and accounts of the selected banks in Nigeria (see appendix for the list of the banks).

The panel data analysis has been carried out to find out the determinants of audit fees in Nigerian bank industry. The panel character of data allows for the use of panel methodology. The panel data estimations areconsidered most recent and efficient analytical methods in handling of econometric data of this kind. The paneldata model is a powerful and strong research instrument. The combined panel data matrix set consists ofa time series for each cross sectional member in data set, and of variety of estimation methods. Themain purpose of using panel data is because it provides the more efficient estimation of parameter byconsidering broader source of variation, outsource more information to researcher and it allow thestudy of dynamic behavior parameters.

\subsection{The Empirical Model}

The sample consists of $\mathrm{N}$ cross sectional units (14-Banks) that are observed at different T-timeperiods (from 2008 to 2012).It is important for a corporation to know how its corporate structure and operating results affect audit fees. The empirical model seeks to establish a link between the determinants and audit fees charged to the top 14 bank-financial services institutions in Nigerian economy. From the words of Swanson (2008), many empirical studies incorporate the same variables in their studies to explain as much of the audit fees as possible. For instance, audit fees tend to increase with an increase in the client's size (Simunic, 1980), risk (Stice, 1991), complexity (e.g., Hackenbrack\&Knechel, 1997), and profitability (e.g., Hay, Knechel\& Wong, 2006). However, audit firm attributes are also considered important drivers of audit fees. Size, reputation, experience, competition, industry specialization and whether it is from the Big Four are aspects of the audit company attributes that influence audit fees. Also, many prior studies suggested that audit fees increase with the Audit firm's Size (Francis, 1984; Palmrose, 1986), reputation (Larcker\& Richardson, 2004, Gonthier\&Schatt, 2007), experience, industry specialization (Pearson \&Trompeter, 1994; Cullinan, 1998) and whether it is one of the Big Four (Palmrose, 1986; Francis \& Simon, 1987; Butterworth \& Houghton, 1995). In addition, audit fees decreases with the increase in competition, the greater the number of competitors the lower the audit fees are charged (e.g., Maher, Tiessen, Colson \& Broman, 1992).

Following the above discussion, consider following equation:

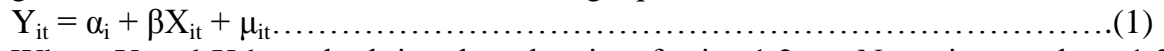

Where $\mathrm{Y}$ and $\mathrm{X}$ have both $\mathrm{i}$ and $\mathrm{t}$ subscripts for $\mathrm{i}=1,2 \ldots . \mathrm{N}$ sections and $\mathrm{t}=1,2, \ldots \mathrm{T}$ timeperiod. $\mathrm{Y}_{\text {it }}$ represents the dependent variable in the model which is the Audit fees and its determinants, $X_{\text {it }}$ contain set of explanatory variables in the estimation model and $\alpha$ is the taken to beconstant over time $t$ and specific to the individual cross section unit i . If $\alpha$ is taken to be the sameacross unit then ordinary least square (OLS) provides a consistent and efficient estimate of $\alpha$ and $\beta$, but this study employs the fixed effect estimator, simply to take care of unobserved heterogeneity such as managerial philosophy within the Nigerian bank industry which is assumed to vary but time-invariant.

This study adopts and modifies the model of Swanson (2008) to explain the relationship between the audit fees and its determinants in Nigerian bank industry.The Swanson's model states that:

Audit fees $=f($ total assets, sales revenues, net income, number of employees $)$.........(2)

For the purpose of this study, the equation (2) is,therefore, modified as shown in equation (3)

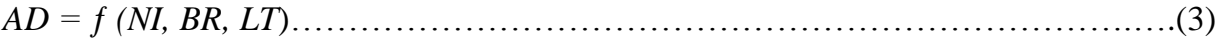

In specific form,

$\mathrm{AD}_{\mathrm{it}}=\alpha_{\mathrm{i}}+\beta_{1} \mathrm{NI}_{\mathrm{it}}+\beta_{2} \mathrm{BR}_{\mathrm{it}}+\beta_{3} \mathrm{LT}_{\mathrm{it}}+\mathrm{u}_{\mathrm{it}}$

3.2Measurement of Variables and Apriori- expectations

(AD) Audit fees $=$ the explained variable

(NI)Net income $\mathrm{it}_{\mathrm{it}}=$ measurement of performances of bank (i) at time (t)

(BR)Number of branches it $=$ measurement of complexity of bank (i) at time (t)

(LT)Liabilities to total assets ratio $_{i t}=$ measurement of risk of bank (i) at time (t)

$\mathrm{u}_{\mathrm{it}}=$ error term

while $\alpha_{\mathrm{i}}$ is the intercept, $\beta_{1}, \beta_{2}, \beta_{3}$ are the coefficient parameters to be estimated. 
The expectation is that; $\alpha_{\mathrm{i}}, \beta_{1}, \beta_{2}, \beta_{3} \square 0$

\section{Discussion of Results}

From the empirical result, the estimated model was obtained and stated as shown in the appendix(Table 1). The coefficient of Number of branches (BR) and Liabilities to total assets ratio (IT) are positive which follows the apriori expectations meaning that both exhibit positive relationship with the Audit Fees (AD). While the parameter of Net Income (NI) exhibits negative relationship with AD. It means that a unit increased in BR will lead to 0.00112 increases in AD on average; similarly, a unit increased in IT will make AD to increase by 6287.191 on average. On the other hand, a unit increased in NI will to a fall in $\mathrm{AD}$ by 70.86 on average. All, the parameters of the model are significant at $5 \%$ level of significance. The coefficient of determination $\left(\mathrm{R}^{2}\right)$ reflects that $96.8 \%$ variation in the $\mathrm{AD}$ is explained by the model. The value of F-calculated of 100.5665 is a clear indication that the model passes the test of overall significant at $5 \%$ level of significance. In addition, Durbin-Watson test (D) statistic is 2.97 which is compared with the tabulated values (Lower limit $\left(D_{L}\right)$ of 1.525 and Upper limit $\left(D_{U}\right)$ of 1.703) shows no evidence of positive first-order serial correlation.

By looking at the above analyses, the positive relationship between the AD and the number of branches offered a clear indication that there is a positive relationship between complexity of banks and audit fees. This suggests that it will take an audit firm much time and effort to visit different locations and networks of a bank for audit exercise purposes. Hence, it reveals that audit firms will charge higher fees, if a bank has wider network system. However, the parameter of Net income (NI) gives a negative relationship between Audit fees and Net income. And, it is significant. Since, net income measures the operating performance of banks, the result suggests that if a bank performs profitably, the level to which it exposes to risk vulnerability tends to reduce. Hence, it pays lower audit fees. In addition, Liabilities to total assets ratio is a mean of measuring level of leverage or risk of a corporate body, the result shows that the higher the risk of a bank the higher the audit fees chargeable by audit firm in Nigerian bank industry. Contrarily, the lower the risk, the lower the audit fees charged. This view is supported by Hassan \&Naser (2013);Simunic (1980), Stice, (1991), Hackenbrack\&Knechel (1997).

\section{Conclusion}

In conclusion, the study focuses on the determinants of audit fees in Nigerian banking industry. The uniqueness of this study is the Panel data analysis used. The Panel data model encompasses three variables (such as complexity, risk and operating performance) which lead to the conclusion that these variables are significant and have a greater influence on the determination of audit fees in Nigerian commercial banking industry. Hence, it can be further said that the view of this study is consistent with the findings of Swanson (2008) who studied the determinants of audit fees for financial institutions in USA, and the work of Akinpelu, Omojola, Ogunseye\&Bada (2013) that examined the link between audit fees and its determinants in Nigerian banking industry.

\section{References}

[1] Akinpelu, Y. A. O., Omojola, S.O., Ogunseye, T. O.\&Bada O. T. (2013).The pricing of audit services in Nigeria commercial banks. Research Journal of Finance and Accounting 4(3),74-80.

[2] Ali,B. C. \& Amiens C. \&Lesage, C. (2011). Ownership concentration and audit fees: do auditors matter most when investors are protected least? Paris, France: HEC School of Management (GREGHEC).

[3] American Accounting Association (AAA, 1973). Committee on basic auditing concepts,a statement of basic auditing concepts. Florida, Sarasota.

[4] Ball, R. (2001). Infrastructure requirements for an economically enceinte system of publicfinancial reporting and disclosure. Brookings-Wharton Papers on Financial Services no.1,127-169.

[5] Banks and Other Financial Institutions Act ( BOFIA, 1991)-Central Bank of Nigeria. Available online at www.cenbank.org/..../1991/BOFIA.PDF. Accessed on 23th September, 2013.

[6] Black, B. (2001). The legal and institutional preconditions for strong Securities Markets.UCLA Law Review no. 48, 781-856.

[7] Butterworth, S., \& Houghton, K. A. (1995). Auditor switching: The pricing of audit services. Journal of Business Finance and Accounting, 22(3), 323-344.

[8] Companies and Allied Matters Act ( CAMA, 2004) CAP C20, Law of the Federal Republic of Nigeria, 2004(amended). Available online at www.nigeria-law.org/..../comp. accessed on 20th June,2013.

[9] Cullinan, C. (1998). Evidence of non-big 6 market specialization and pricing power in a niche assuming service sector. Auditing, A Journal of practice and theory, 17(supplement), 47-57.

[10] Doogar, R. \&Easley,R.(1998). Concentration without differentiation: A New look at the determinants of audit Market Concentration. Journal of Accounting and Economics: 235-253.

[11] Ellis, Y., \& Booker, Q. L. (2011). Audit fee determinants in the nonprofit sector: A study of community action agencies. Columbia State University: Faculty Publications.

[12] El-Gammal, W. (2012). Determinants of Audit Fees: Evidence from LebanonInternational Business Research, 5(11), 136-145.

[13] Friis,O. \&Nielsen,M. (2010). Audit fees and IFRS accounting: Is information costly? Discussion Papers on Business and Economics No. 3/2010,University of Southern Denmark. Available online at //www.sdu.dk/osbec,accessed on $30^{\text {th }}$ September, 2013 .

[14] Francis, J. R. (1984). The effect of audit firm Size on audit Prices: A study of theAustralian Market. Journal of Accounting and Economics, 6(2),133- 151. 
[15] Gerakos, J. \&Syverson,C. (2013). Competition in the audit Market: Policy implications. University of Chicago Booth School of Business: faculty publication.

[16] Gonthier, B., \&Schatt, A. (2007). Determinants of audit fees for French quoted firms. Managerial Auditing Journal, 22(2), 139-160.

[17] Hackenbrack, K. \&Knechel, W.R. (1997). Resource allocation decisions in audit engagements. Contemporary Accounting Research 14 (1997), 481-499.

[18] Hallak, R. T. \& Da Silva, A. L. C.(2012). Determinants of audit and non-audit fees provided by independent auditors in Brazil. Rev. contab. finanç.23 (60) São Paulo Sept./Dec. 2012. Available online at http://dx.doi.org/10.1590/S1519-70772012000300007. Accessed on 21th November,2012.

[19] Hassan,Y. M. \&Naser, K.(2013). Determinants of audit fees: Evidence from an emerging economy. International Business Research, 6(8), 13-25.

[20] Hayes ,Schilder, Dassen \& Wallage, P. (2005). Principles of auditing: An international perspective . New York: McGraw-Hill Higher Education

[21] Hay, D. W., Knechel. R. \& Wong, N. (2006). Audit fees: A meta-analysis of the effect of supply and demand attributes. Contemporary Accounting Research, 23(2006), 141-191.

[22] Ionela-Corina C. ,Ioan-Bogdan R. , Mihai Carp \&Marilena M. (2012). A Circular causality analysis on the determinants of the audit fees within the NYSE-quoted companies. IBIMAPublishing Communications of the IBIMA. Available online at http://www.ibimapublishing.com/journals/CIBIMA/cibima.html. accessed on 20th November,2013.

[23] Ittonen, K. (2010).A Theoretical examination of the role of auditing and the relevance of audit reports. VaasanYliopistonJulkaisuja, Proc. of the University of Vaasa. Teaching Aid Series. PP. 1-70

[24] Larcker, D., \& Richardson, S. (2004). Fees paid to audit firms, accrual choices, and corporate governance. Journal of Accounting Research 42(2004), 625-658.

[25] Limperg, T. (1932). Theory of inspired confidence. University of Amsterdam.Maher, M., Tiessen, P., Colson, R., \& Broman, A. (1992). Competition and audit fees. The Accounting Review, 67(1), 199-211.

[26] Palmrose Z.-V. (1986). Audit fees and auditor size: Further evidence. Journal of Accounting Research,24(1), 97-110.

[27] Pearson, T., \&Trompeter, G. (1994). Competition in the market for audit services: The effect of supplier concentration on audit fees. Contemporary Accounting Research, 11(1), 115-135.

[28] Simunic, D. A. (1980). The pricing of audit services: Theory and evidence. Journal of Accounting Research, 18(1),161-190.

[29] Shammari, B. A., Yaqout, A. A.\&Hussaini, A. A. (2008). Determinants of audit fees in Kuwait. International Academy of Business and Economics,8( 1), 1-7.

[30] Stice, J .(1991). Using financial and market information to identify pre-engagementfactors associated with lawsuits against auditors. The Accounting Review 66,516-33.

[31] Swanson, K. (2008). The determinants of audit prices for financial services institutions in the United States. Major Themes in Economics, Spring 2008. Available online at www.business.uni.edu/..../kswanson.pdf. accessed on 23th Feburary,2013

[32] Watts, R., \& Zimmerman, J. (1983). Agency problems, auditing and the theory of the firm: Some evidence. Journal of Law \& Economics, 26 (3), 613-634.

\section{Appendix}

Table: 1- Results showing the estimated coefficients of the model

\begin{tabular}{crrrr}
\hline \hline Variable & Coefficient & Std. Error & t-Statistic & Prob. \\
\hline \hline C & 13338.77 & 5159.141 & 2.585462 & 0.0125 \\
BR & 0.001122 & 0.000201 & 5.592628 & 0.0000 \\
NI & -70.86950 & 24.11714 & -2.938553 & 0.0049 \\
IT & 6287.191 & 1349.526 & 4.658814 & 0.0000 \\
Fixed Effects (Cross) & & & & \\
ACC-C & $1.83 \mathrm{E}-13$ & & & \\
UBA-C & $1.83 \mathrm{E}-13$ & & & \\
ECO-C & $1.83 \mathrm{E}-13$ & & & \\
FCM-C & $1.83 \mathrm{E}-13$ & & & \\
FIDE-C & $1.83 \mathrm{E}-13$ & & & \\
GTB-C & $1.83 \mathrm{E}-13$ & & & \\
STER-C & $1.83 \mathrm{E}-13$ & & & \\
UBN-C & $1.83 \mathrm{E}-13$ & & & \\
WEMA-C & $1.83 \mathrm{E}-13$ & & & \\
DIAM-C & $1.83 \mathrm{E}-13$ & & & \\
FIRST-C & $1.83 \mathrm{E}-13$ & & & \\
ZEN-C & $1.83 \mathrm{E}-13$ & & & \\
UNITY-C & $1.83 \mathrm{E}-13$ & & & \\
SKY-C & $1.83 \mathrm{E}-13$ & & & \\
\hline
\end{tabular}

Source: Author's computation 
Table: 2- The list of Commercial banks used in the study

\begin{tabular}{|l|l|}
\hline Names of Banks & Acronyms used \\
\hline Access Bank & ACC \\
\hline United Bank for Africa & UBA \\
\hline Eco Bank & ECO \\
\hline First City Monument bank & FCM \\
\hline Fidelity Bank & FIDE \\
\hline Guaranty Trust Bank & GTB \\
\hline Sterling Bank & STER \\
\hline Union Bank of Nigeria & UBN \\
\hline Wema Bank & WEMA \\
\hline Diamond Bank & DIAM \\
\hline First Bank & FIRST \\
\hline Zenith Bank & ZEN \\
\hline Unity Bank & UNITY \\
\hline Skye Bank & SKY \\
\hline
\end{tabular}

